(C) 2020 Katedra Białorutenistyki UW. Wydanie w otwartym dostępie na licencji CC BY-NC-ND (https://creativecommons.org/licenses/by-nc-nd/4.0/deed.pl)

ACTA ALBARUTHENICA 20: 2020

DOI: 10.32612/uw.18988091.2020.20.pp.209-219

Кацярына Любецкая / Liubetskaya Katsiaryna

Беларускі дзяржаўны ўніверсітэт / Belarusian State University

ORCID: https://orcid.org/0000-0002-7318-9583

e-mail: katerina_lingvo@mail.ru

\title{
Станаўленне навуковага стылю беларускай мовы ў пачатку XX ст.
}

The formation of the scientific style of the Belarusian language in the early twentieth century

Kształtowanie się stylu naukowego języka białoruskiego na poczq̨tku XX wieku

У ункцыянальнай разнавіднасцю літаратурнай мовы, якая аб'ядноўвае мову розных галін навукі і служыць для перадачы аб’ектыўнай інфармацыі аб акаляючым асяроддзі, з'яўляецца навуковы стыль.

Самымі агульнымі спецыфічнымі рысамі навуковага стылю, якія вынікаюць з паняційнасці і строгай лагічнасці мыслення, з'яўляюцца абстрактнасць, абагульненая падача матэрыялу, лагічнасць, дакладнасць у вызначэнні паняццяў, выразнасць выкладання [Лексікалогія сучаснай беларускай літаратурнай мовы 1994: 324].

Фармаванне навуковага стылю ў мовах свету адбываецца ў адрозных гістарычных умовах, што ў цэлым цесна звязана з агульным працэсам стварэння іншых моўных стыляў.

У літаратурных мовах (англійскай, французскай, нямецкай, рускай), грамадскае функцыянаванне якіх гістарычна не абмяжоўвалася і не ўскладнялася якімі-небудзь стрымліваючымі ўплывамі, навуковы стыль ў асноўным фармаваўся паралельна са стылямі публіцыстычным, афіцыйнасправавым [Высоцкая 2013: 21].

Навуковы стыль беларускай мовы пачаў фармавацца значна пазней за іншыя стылі. Яго станаўлення цесна звязваецца $з$ асаблівасцямі фармавання і функцыянавання беларускай мовы ў сацыяльна-гістарычным і культурна-палітычным кантэксце ў пачатку XX ст. і адбываецца перадусім практычным шляхам згодна 3 тым, як шырыцца друкаванне на беларускай мове, развіваецца нацыянальная школа, выходзяць працы навуковай тэматыкі.

У пачатку XX ст. беларуская літаратурная мова некалькі пашырыла сферы свайго выкарыстання і ў сістэме яе моўна-выяўленчых сродкаў пачала фарміравацца тэрміналагічная лексіка [Красней 2011: 111]. 
Актуальныя працэсы развіцця навуковага стылю неаднаразова вывучаліся ў беларускай філалогіi. Разгляду гэтай функцыянальнай разнавіднасці беларускай мовы прысвяцілі свае працы такія навукоўцы, як Мікалай Абабурка, Уладзімір Анічэнка, Іван Лепешаў, Таццяна Старасценка, Міхаіл Цікоцкі, Алена Юрэвіч і інш. Комплексных даследаванняў, прысвечаных станаўленню навуковага стылю беларускай мовы ў пачатку XX ст., яшчэ не было праведзена, што робіць вывучэнне гэтага пытання актуальным. Мяркуем, што праз разгляд матэрыялаў навуковай тэматыкі 1900-1920 гг. зробіцца магчымым ахарактарызаваць асаблівасці моўна-стылістычнага афармлення гэтых тэкстаў, вылучыць адметныя рысы навуковага выкладу ў беларускай мове ў пачатку XX ст.

Першыя дваццаць гадоў XX ст. у беларускім мовазнаўстве прынята вылучаць у асобны перыяд, які разглядаюць як

надзвычай змястоўны і ў параўнанні з папярэднімі перыядамі характарызуецца пэўнымі зрухамі як у самім падыходзе грамадскасці да беларускай мовы, так і ў яе навуковай распрацоўцы [Шакун 1996: 76].

Уздым нацыянальна-вызваленчага руху ў краіне абумоўлівае развіццё друку на нацыянальных (у тым ліку і беларускай) мовах, станаўленне школьніцтва на беларускай мове.

Восенню 1915 г. у выніку ваенных дзеянняў паміж Германіяй і Расіяй тэрыторыя сучаснай Беларусі была падзелена: лінія фронту тады працягнулася ад Дзвінска ўздоўж возера Нарач праз Баранавічы да Пінска. Пад нямецкі кантроль трапілі заходнія губерні імперыі - Гродзенская, часткова Віленская і Мінская, а царскія войскі занялі Усходнюю Беларусь з гарадамі Мінск, Барысаў, Бабруйск, Мазыр. На тэрыторыі, занятай немцамі, быў створаны вайсковы адміністрацыйны абшар (т. зв. Обер Ост) пад кіраўніцтвам фельдмаршала Паўля фон Гіндэнбурга, улады якога апынуліся перад даволі складанай праблемай кіравання шматнацыянальным рэгіёнам [Любецкая 2002: 12].

Пастаўленыя перад неабходнасцю вырашэння моўнага пытання, акупацыйныя ўлады прынялі за прынцып аднолькавае стаўленне да ўсіх нацыянальнасцей. Ваенным адміністрацыйным рэжымам прадугледжвалася правядзенне культурнай дзейнасці, якая ўключала ў сябе стварэнне нацыянальных тэатраў, тэатральных труп, выданне газет на ўсіх нацыянальных мовах, а таксама абавязковае навучанне дзяцей у пачатковых школах на роднай мове.

Prykazam z dnia 7 czerwienia 1916 h. vydany instrukcii ab sposabi ŭpraŭleńnia zaniatymi ziemlami. U instrukcijach asabliwa adznaczywajecca žadańnie, kab roznyje narody mieli-by roŭnyje prawy. Usio, czym naruszajecca zhodliwaje žyćcio narodaŭ, zabaraniajecca. Za naruszeńnia hetaho karacimuć sztrafam hraszmi da 10.000 marak abo wastroham da 5 hadoŭ. Oficyalnaj mowaj liczycca miž ułaściami i nasialeńiem pazwolena ǔžywać biełaruskaj, łatyszskaj, litoŭskaj, polskaj i žydoŭskaj mowy [Ab upraŭleńni ziemlami Ober Ost 1916, №43: 3]. 
Ва ўмовах ажыўлення беларускага нацыянальнага руху на тэрыторыі Усходняй Беларусі ў 1917 г. утвараецца Беларускі нацыянальны камітэт, які пасля змен пераўтвараецца ў Вялікую Беларускую Раду.

Важнай сферай дзейнасці народнага сакратарыята ${ }^{1}$ было школьніцтва. Пры народным сакратарыяце асветы было створана бюро па справах распрацоўкі школьных падручнікаў і таварыства “Прасвета", якое занялося іх выданнем. Былі арганізаваны настаўніцкія курсы і школьная інспекцыя, пашырылася сетка пачатковых і сярэдніх школ. У Мінску быў створаны Беларускі педагагічны інстытут <..>. Рыхтавалася адкрыццё ўніверсітэта. Працавалі ў Мінску Беларускі тэатр, Таварыства драмы і камедыі і іншыя культурныя ўстановы. Пад кантролем народнага сакратарыята выходзіла больш дзясятка газет і часопісаў на беларускай мове [Туронак 1993: 22].

У гэты час арганізуецца праца беларускіх выдавецтваў. “Галоўнымі асяродкамі выдавецтваў у тым часе былі Вільня, Мінск, Пецярбург i Масква" [Głogowska 1996: 55]. Беларускія тэксты рознага жанравастылявога характару рыхтуюцца ў Вільні ("Наша ніва", "Наша хата", “Беларускае выдавецкае таварыства”), у Мінску (“Мінчук”), у Пецярбурзе (выдавецтва А. Грыневіча, “Загляне сонца і ў наша аконца”), а таксама ў іншых гарадах краю, напрыклад: “Палачанін”, “Вясёлкі”, “Агранамічнае бюро К. Карповіча".

Менавіта на пераломе 1910-1920 гг., на думку беларускіх даследчыкаў, пачынаецца “інстытуцыялізванае даследаванне нацыянальнай мовы беларускага народа...” [Запрудскі 2003: 3]. У Вільні ствараецца Беларускае навуковае таварыства.

У 1919 г. была створана Тэрміналагічная камісія з мінскіх настаўнікаў, якая распрацавала асноўныя тэрміны для беларускай школы, надрукаваныя потым у “Праграме беларускай пачатковай школы” на 1919/1920 навучальны год [Плотнікаў 2003: 360].

У гэты перыяд найбольшая ўвага скіроўваецца на распрацоўку беларускай літаратурнай мовы і яе ролі ў грамадскім жыцці. На думку беларускага палітычнага дзеяча, гісторыка Яўсея Канчара, што ў 1918 г. выказваў свае меркаванні пра беларускую мову,

сярод беларусаў існуе некалькі меркаванняў на дэталі беларускага адраджэння. Але няма ўжо ніводнага Беларуса, калі ён сябе такім лічыць, які б не прызнаваў беларускага Пытання ў цэлым і пазбягаў бы працаваць над паляпшэннем гэтага Пытання. Затое такая падрабязнасць, як выпрацоўка літаратурнай беларускай мовы, выклікае шмат спрэчак і мае сваіх заўзятых праціўнікаў і абаронцаў [гл. Запрудскі 2003: 167].

Асобна пытанні станаўлення мовы беларускай навукі і навуковага стылю па аб'ектыуных прычынах яшчэ не могуць быць узнятыя. Разам

${ }^{1}$ Народны сакратарыят - выканаўчы орган Вялікай Беларускай Рады.

2 Больш падрабязна пра дзейнасць выдавецтваў [гл. Głogowska 1996: 51-57; Гапоненка 2012: 21-25]. 
з тым гэты перыяд характарызуецца пэўнымі зрухамі ў развіцці беларускай мовы і яе функцыянальна-стылістычнай разгалінаванасці: у друку абмяркоўваюцца пытанні развіцця і ўдасканалення беларускай літаратурнай мовы, выпрацоўкі яе сродкаў, графікі, нацыянальнага правапісу.

Даследчыкамі заўважаецца, што ў першыя дзесяцігоддзі XX ст. “пытанні развіцця беларускай літаратурнай мовы, яе нармалізацыі, ролі ў грамадскім жыцці, у адраджэнні нацыянальнай культуры разглядаліся амаль выключна тагачаснай прэсай, як трэба было чакаць - галоўным чынам у публіцыстычным плане" [Шакун 1995: 80]. У газетах "Наша доля", "Наша ніва", “Гоман”, “Дзянніца", “Светач”, "Вольная Беларусь”, "Biełarus” і інш., часопісах “Саха”, “Раніца”, “Лучынка”, календарах, альманахах "Маладая Беларусь" публікуюцца артыкулы, прысвечаныя асвятленню пытанняў з розных сфер навукі, з'яўляюцца асобныя беларускія падручнікі па розных галінах ведаў, у прыватнасці беларускія граматыкі А. Луцкевіча, Р. Абіхта, Б. Пачобкі, Я. Станкевіча, А. Смоліч, К. Каганца, кнігі для чытання, задачнікі.

Практычная дзейнасць па выданні матэрыялаў навуковай тэматыкі ў пачатку XX ст. ставіць аўтараў тэкстаў перад неабходнасцю выбару тых або іншых моўных сродкаў для пабудовы навуковага маўлення. Відаць, у гэты перыяд яшчэ рана казаць пра сістэмны падыход да выпрацоўкі асноў навуковага выкладу ў беларускай мове. Пры выбары моўных сродкаў для складання тэксту навуковай тэматыкі аўтары кіруюцца пераважна ўласным бачаннем і меркаваннем адносна шляхоў фармавання беларускай мовы ў гэты перыяд. У гэтай сувязі можна пагадзіцца з меркаваннем, што

хоць сур'ёзных прац па пытаннях нармалізацыі сродкаў беларускай літаратурнай мовы ў пачатку XX ст. яшчэ не паяўлялася, аднак паступова назапашваўся і абмяркоўваўся неабходны для гэтага матэрыял [Шакун 1995: 82].

у цэлым можна прадугледжваць, што ў першыя дзесяцігоддзі XX ст. падрыхтоўка і далейшая публікацыя беларускамоўных тэкставых матэрыялаў рознай тэматыкі, зместу і прызначэння спрыяла станаўленню працэсу дыферэнцыяцыі беларускай мовы ў функцыянальна-стылістычным плане, выпрацоўцы грамадска-ўсвядомленых норм ужывання моўных сродкаў у асобных стылях.

Афіцыйнае становішча беларускай мовы вызначыла развіццё жанраў пісьменнасці, стылявую дыферэнцыяцыю і ступень літаратурнай апрацаванасці беларускай літаратурнай мовы [Гісторыя беларускай літаратурнай мовы 1968: 116].

У гэты час выдаецца арыгінальная і перакладная літаратура "даступная для ўсіх". У тэкстах навуковай тэматыкі рэалізуецца перадусім функцыя перадачы навуковай інфармацыі. Варта памятаць пры гэтым, што ў тагачаснай прэсе асноўнай аўтарскай задачай робіцца зацікавіць 
чытача навуковай інфармацыяй і папулярна, у даступнай форме выкласці матэрыял. У сувязі з гэтым для інтэрпрэтацыі навуковай інфармацыі ва уммовах фармавання навуковага стылю робіцца найбольш прымальнай папулярная форма. У вучэбна-педагагічных тэкстах і падручніках першых двух дзесяцігоддзяў XX ст. разглядаюцца зыходныя звесткі па мове з мэтай навучыць чытаць па-беларуску.

Станаўленне навуковага стылю беларускай мовы 1900-1920 гг. закладваецца ў некалькіх асноўных жанравых формах: у сродках масавай інфармацыі: артыкул навуковай тэматыкі, рэцэнзія, крытыка-біяграфічны нарыс, навуковая брашура, кніжны агляд, а вучэбна-педагагічнай літаратуры: граматыка, падручнік для пачатковай школы.

Ужо ў першых тэкстах можна назіраць, што моўны матэрыял арганізуецца паводле пэўных структурна-кампазіцыйных прымет. Напрыклад, даследчыкамі заўважана, што некаторыя тэксты, што друкаваліся ў газетах, "пабудаваны наступным чынам: уводзіны да прадмета гаворкі, яго характэрныя прыкметы ці асаблівасці, якое дачыненне мае да чытача, заканчэнне” [Мова “Нашай Нівы” 2014: 330]. Да адметных характарыстык тэксту навуковай тэматыкі гэтага часу можна аднесці таксама ўвядзенне ў яго структуру г. зв. нямоўных знакаў: лічбаў, схем, табліц, чарцяжоў. У структуры граматыкі Браніслава Тарашкевіча з мэтай агульнай катэгарызацыі навуковага зместу, мяркуемага абдумвання навуковых звестак асноўны матэрыял размеркаваны па асобных раздзелах з адпаведнай нумарацыяй.

У гэты час падрыхтоўка матэрыялаў пэўнай жанравай формы абумоўлівае увядзенне ва ўжыванне аўтарамі новых сродкаў выражэння, спецыфічных для навуковых зносін слоў, словазлучэнняў, канструкцый.

У матэрыялах навуковага выкладу, надрукаваных у сродках масавай інфармацыі, звычайна назіраюцца адступленні ад нейтральнай танальнасці і выражаюцца адносіны асобы да рэчаіснасці, перадаецца аўтарская ацэнка. Эмацыянальнасць выкладу навуковай інфармацыі забяспечваецца ўжываннем слоў з памяншальна-ласкальнымі суфіксамі: дрэуцо, сонейка, лясочэк, узгорачэк, паўнютынька, эпітэтаў: народнаго духа, у жывой мове, гразь культуры, злые здарэньня, устойлівых спалучэнняў: нічога кепскаго, нечаго негаданаго.

Характарызуючы моўныя рысы тэкстаў навуковай тэматыкі гэтага часу, можна адзначыць пэўную адвольнасць у выбары моўных сродкаў пры падрыхтоўцы тэксту. Натуральна, у гэты час яшчэ рана весці гаворку пра сістэмнасць асобных функцыянальна-стылістычных разнавіднасцей беларускай мовы. Моўныя тэксты гэтага часу характарызуюцца спецыфічнай лексікай і своеасаблівым сінтаксічным ладам.

Паколькі навуковыя матэрыялы арыентуюцца перадусім на запатрабаванні простага чалавека, яны напісаныя жывой народнай мовай. Найбольшую групу ў тэкстах навуковага выкладу складаюць нейтральныя словы, без эмацыйна-экспрэсіўнай афарбоўкі, словы агульнаўжывальнай лексікі, што сустракаюцца ва ўсіх стылях мовы. Такія словы 
з'яўляюцца найменнямі навакольнага свету, рэчываў, прасторы, часу і інш.: вада, сонцэ, морэ, вйоска, вымогі, горад, гутаркі, малака, народам, praйdu, сем'я, чытач.

Істотным элементам кампазіцыйнай будовы гэтых тэкстаў і вызначальным стылеўтваральным фактарам робіцца лексіка, выкарыстаная аўтарамі для перадачы спецыяльнага значэння. Такая лексіка (шляхам яе паўтору ў тэкстах навуковай тэматыкі) выконвае важную архітэктанічную, кампазіцыйную функцыю. Дзякуючы выкарыстанню найменняў для перадачы спецыяльных паняццяў, ужыванне якіх скіравана на забеспячэнне ўнутранага адзінства моўнай сістэмы тэксту, ствараецца г. зв. спецыяльны кантэкст. У гэты час у беларускай мове працэс выпрацоўкі тэрміналагічнай і абстрактнай лексікі і фразеалогіi толькі пачынаецца.

Было яшчэ вельмі далёка да таго, каб беларуская мова атрымала шырокія правы ва ўсіх сферах грамадскага жыцця. Тым не менш тыя зачаткі навуковай тэрміналогіi, што былі ў гэты перыяд, паказваюць, што і ў гэтай сферы беларуская мова асаблівых, непераадоленых цяжкасцей не сустракала: яна папаўняла свой слоўнікавы запас з існуючых крыніц шляхам запазычанняў, калькавання і г. д. , інакш кажучы, магла ўзяць на сябе і гэту функцыю [Гісторыя беларускай літаратурнай мовы 1968: 150].

у тэкставых матэрыялах можна вылучыць лексічныя адзінкі, суадносныя з такімі галінамі ведаў, як грамадска-палітычныя навукі, астраномія, філасофія, правазнаўства, мовазнаўства, літаратуразнаўства, выдавецкая дзейнасць, мастацтва, матэматыка, эканоміка, ваенная справа. Канешне, характарызуючы пачаткі тэрмінатворчай дзейнасці 1900-1920 гг., можна казаць толькі пра першыя крокі ў справе вызначэння падыходаў да выпрацоўкі спецыяльнай лексікі ў беларускай мове. Даволі заўважнымі ў гэты час робяцца пурыстычныя тэндэнцыі ў галіне выпрацоўкі намінацый спецыяльнага значэння.

Пры фармаванні намінатыўна-тэрміналагічнага фонду прынцып арыентацыі на іншамоўныя тэрміны інтэрнацыянальнага характару быў мінімальным, у адрозненне ад дамінуючага прынцыпу максімальнага выкарыстання ўласных моўных сродкаў [Любецкая 2017: 302].

У тэкстах навуковай тэматыкі для перадачы спецыяльнага значэння ўжываліся перадусім словы ўласнабеларускія: адусюль, бульбяны, галлё, гутарка, дагэтуль, жудасны, завіруха, імшар, колішні, надвор'е, падвячорак, ралля, спрадвеку, туляга, узмежак, хаўтуры, чутка, шанцаваць. У навукова-папулярныя творы пачатку XX ст. уводзіліся словы дыялектныя: тагды, можыць, пішыць, бываіць, караець, тхлань, харонга, цвікёль, пячкур, вогнік, бросьня. Даволі часта ў якасці спецыяльнай лексікі выступаюць народныя найменні: вар, бусел, груд, гуз, дзяцеліна, закелзаць, злыбеда, каліва, летась, сёлета, апісальныя паняцці, параўн.: раней тэрміну (дасрочны), пераварачыванне з адной 
нацыі у другую (асімілящыя), лячэнне жывёлы (ветэрынарыя), падземная дарога - (тунель).

Робяцца звычайнымі словы і словазлучэнні, што ў далейшым замацаваліся як тэрміны з галін філалогіі: бэлетрыстыка, літара, апавяданьня, мова, значэнне, шрыфт, філологічны, правазнаўства: абавязак, аб роўнасьці, вобыск, закон, забараняещца, конфіскація, прыгавор, грамадазнаўства: губэрнатар, ваеннаакружны, ідэалогія, інспэктар, констытуція, рэволюцыйны, парлямэнт, земства, манаполія, палітыка, солідарнасьць, уполномочэны, правіцельство, школа, упраўленьне, сельская гаспадарка: аграном, гумно, збожжэ, да пасевоў, садаводаў, сена, зернятка, жыто, ураджай, эканомікі: крэдытар, коопэрація, эканаміст, акціонерны, медыцына: амбуляторыя, рэбры, ортопэдычны, псыхіатрычна, філасофіі: філёзаф, постулят, катэдра, ваеннай справы: тэатр ваенных змаганняў, армія, глаўнакамандаючы, партызанскі, пісталет, раскватэроўка, штаб. Канкурэнтнымі ў спецыяльнай сферы выступаюць такія беларускія і запазычаныя намінацыі, як дэкларацыя - праграма, урад - правіцельства, каморнік - землямер, установа інстытуцыя, кан'юнктура - будоўля.

Варта адзначыць, што падрыхтоўка прац навуковага характару ў гэты час спрыяе назапашванню неабходнага матэрыялу для далейшага вызначэння шляхоў і спосабаў фармавання айчыннага тэрмінафонду і выпрацоўкі мовы навукі.

Адной з крыніц фармавання мовы навукі стала запазычванне з суседніх моў. Пры намінаванні паняццяў, якія перадавалі спецыяльнае значэнне, аўтары звярталіся да запазычанняў з рускай мовы, напр.: amчот, аружжа, вучылішча, гасударства, папячыцель, шчатаводства, з польскай, напр.: зыск, малатарня, натаваць, часопісь, ягомасць, з украінскай, напр.: надаслаць, напярэдадні, чытач. “Сярод тыпова рускіх марфем <...> можна назваць суфікс -цель: абвініцель, валадзецель, пісацель, прадсядацель, прадацель, попячыцель" [Гапоненко 2018: 197].

Адным са спосабаў утварэння намінацый для перадачы спецыяльнага значэння стала калькаванне, напр.: выразнік, вышэйпамянуты, канчатак, светагляд, творства.

Беларускай навуковай мове гэтага часу ўласціва вялікая ступень сінанімічнасці. Ва ўмовах паскоранай распрацоўкі беларускай тэрміналогіі ўзнікалі ў г. зв. навукова-маўленчай практыцы дублетныя тэрміны, напрыклад: памяшчэнне - ангар, рада - бюро, пазычка, павер крэдыт, валасны - гмінны, художэственны - артыстычны, грошавы фінансавы, абшчынны - супольны, хаўрус - кружок.

Для абазначэння мерапрыемстваў і ўстаноў тэкстам навуковай тэматыкі ўласціва выкарыстанне назоўнікаў з суфіксам - ацыя (-ізацыя): арганізацыя, дэпутацыя, цыркуляцыя, эміграцыя, дэнацыяналізацыя, для абазначэння навуковых плыняў і вучэнняў ужываюцца назоўнікі з суфіксам -ызм (-ізм): дэмакратызм, клерыкалізм, нігілізм, патрыятызм, сацыялізм, шавінізм. Актыўным робіцца ўжыванне ў навуковых 
тэкстах адцягненай лексікі з суфіксамі: -асць (-осць), -нн-, -цыј-, -ств(-зтв-, -цтв-), -шч-, напр.: граматнасць, забалочанасць, сьвядомасць, істнаванне, нічоганяробленне, цкаванне, сэлекцыя, эдукація, глупствы, чававечэства, лугаводзтва, судаводзтва, сьледзтва, множства, княжства, чэлавеканенавіснічэства, мінууцччына. Вядомыя таксама вытворныя спалучэнні, напрыклад: маюць право, прыгожаго пісьменства, грамадзянскі догляд, зняць кару, стан пасяданя, грамадская суполка, эканамічныя адносіны, прыватная ўласнасць, ашчадны хаўрус, асноўны капітал.

У тэкстах навуковай тэматыкі пачынаюць выкарыстоўвацца дзеепрыметнікі і дзеепрыслоўі: кніжачка, напісаная так цікава..., абавязываючые пастановы, аглучаючы ўзрыў, полк англіскай пяхоты, ідучый у атаку, мужыкі, падганяныя казацкімі нагайкамі.

У пачатку XX стагоддзя пачынаецца афармленне сінтаксічнага ладу тэкстаў навуковага выкладу. Для перадачы значнага аб'ёму інфармацы аўтары тэкстаў звяртаюцца да рознага тыпу ўскладненняў структуры простага сказа, напрыклад, за кошт устаўных канструкцый: Большая часьць умірае (каля 50 прац.), Kоžnaje słowa - aprača čatyroch niazmiennych časciej mowy - składajecca z dzwiech čaćciej: niazmiennaj asnowy i kančara, katory admieniajecca zaležnie ad taho, u jakich warunkach užywajecca słowa [Luckevič 2017: 54]. Для сувязі з папярэднім кантэкстам у навуковых тэкстах ужываюцца пабочныя словы, напр.: Pieršaje heta toje, što dastać zahraničny pašpart doraha kaštuje - 15 rub. na poǔhoda ["Наша ніва" 1911, 2: 34]. Для выражэння складанага сэнсу аўтары звяртаюцца галоўным чынам да выкарыстання складаных сказаў. Пры гэтым складаныя сказы сустракаюцца часцей, чым простыя, і яны разнастайныя па сваёй структуры: складаназалежныя, складаназлучаныя: Калі нельга друкаваць двума шрыфтамі, трэба выбраць адзін: рускі. Так пісалі ўсе свядомыя беларусы, апрача невялікай жмені [“Наша ніва", 1912. № 42]; Беларускі народ гаварыў і гаворыць рознымі гутаркамі, каторыя мейсцамі блізкі да польскай мовы, мейсцамі - да украінскай, мейсцамі - да расейскай [“Наша ніва”, 1912. № 14]. Сувязь паміж сказамі ў навуковай мове ажыццяўляецца пры дапамозе злучнікаў і злучальных словаў: ня гледзячы на, перад тым як, прычым, з тым каб, у тым ліку, дзякуючы.

Пачатак XX ст. - час закладвання асноў далейшай функцыянальнастылявой дыферэнцы беларускай мовы. У гэты час аўтары намагаюцца не проста ствараць на беларускай мове тэксты рознай тэматыкі і рознага функцыянальнага прызначэння, але пры іх складанні арыентавацца на сацыяльныя, індывідуальныя асаблівасці адрасатаў тэксту, улічваць грамадскую сферу зносін, мэты выказвання. Дзякуючы практычнай дзейнасці аўтараў па падрыхтоўцы беларускіх тэкстаў, розных па мэце і задачах, форме, зместу, паступова пачынаецца г. зв. стылістычная праца ў беларускай мове. Можна прадугледжваць, што ў аб'ектыўных умовах нераспрацаванасці не толькі функцыянальных стыляў, 
але і самой нацыянальнай мовы ў пачатку XX ст. аўтары пры выбары моўнай формы ў сваіх тэкстах кіруюцца пераважна сваімі моўнымі густамі.

Такім чынам, можна адзначыць, што асновай фармавання навуковага выкладу і навуковага стылю ў беларускай мове ў 1900-1920 гг. стала выданне тэкставых матэрыялаў навуковай тэматыкі і развіццё беларускай пісьменнасці. Вывучэнне структуры, мовы і архітэктонікі тэкстаў навуковай тэматыкі першых дзесяцігоддзяў XX ст. дазваляе назапасіць нямала назіранняў адносна асаблівасцей фармавання навуковага стылю беларускай мовы. Натуральна, у гэты час яшчэ толькі закладваюцца асновы функцыянальнай дыферэнцыяцыі стыляў беларускай мовы. На дыферэнцыяцыю стыляў ў гэты перыяд у рознай ступені ўплываюць стан беларускай мовы, моўная практыка аўтараў тэкстаў. Менавіта ў гэты час адбываюцца пачатковыя спробы стварэння прыёмаў, стылістычных сродкаў і спосабаў нацыянальнага навуковага выкладу, выпрацоўваецца кампазіцыйна-структурная будова тэкстаў навуковай тэматыкі, пачынаецца развіццё правапісна-граматычных і лексіка-семантычных норм навуковага тэксту, яго характалагічных моўных і нямоўных элементаў.

\section{Бібліяграфія}

Ab upraŭleńni ziemlami Ober Ost. 1916. „Homan”. № 43.

Anton Łuckiewič: Biełaruskaja hramatyka pawodłuh lekcij, čytanych na Biełaruskich Wučycielskich Kursach u Wilni - ŭ 1915-1916 hh. 2017. Band I, II. Hrsg. von R. Grübel, G. Hentschel, G.-B. Kohler. Edition und Kommentar von H. Bieder unter Mitwirkung von K. Gutschmidt. Oldenburg: BIS-Verlag der Carl von Ossietzky Universität Oldenburg.

Belaruskaâ mova. Lìngvìstyčny kampendyum. 2003. Mìnsk: Ìntèrprèssèrvìs [Беларуская мова. Лінгвістычны кампендыум. 2003. Мінск: Інтэрпрэссэрвіс].

Gaponenka Ìryna. 2012. Leksika belaruskaj litaraturnaj movy XIX - pačatku XX st.: asablìvascì stanaǔlennâ ì razvìccâ. Mìnsk: BDU [Гапоненка Ірына. 2012. Лексіка беларускай літаратурнай мовы ХІХ - пачатку XX ст.: асаблівасці станаўлення і развіция. Мінск : БДУ].

Gaponenko Irina. 2018. Vliânie vostočnoslavânskih âzykov nabelorusskij âzyk načala XX v. "Studia białoruthenistyczne". № 12: 191-213 [Гапоненко Ирина. 2018. Влияние восточнославянских языков на белорусский язык начала ХХ в. "Studia białoruthenistyczne". № 12: 191-213].

Gìstoryâ belaruskaj litaraturnaj movy. Tom II. 1968. Rèd. A. Žuraǔskì. Mìnsk: Navuka ì tèhnìka [Гісторыя беларускай літаратурнай мовы. Том II. 1968. Рэд. А. Жураўскі. Мінск: Навука і тэхніка].

Głogowska Helena. 1996. Białoruś 1914-1929. Kultura pod presją polityki. Białystok: Orthdruk.

Krasnej Vìktar. 2011. Belaruskaâ tèrmìnalogîa. Rèd. M. Prygodzič. Mìnsk: BDU [Красней Віктар. 2011. Беларуская тэрміналогія. Рэд. М. Прыгодзіч. Мінск: БДУ].

Leksìkalogiâ sučasnaj belaruskaj littaraturnaj movy. 1994. Rèd. A. Bahan'koǔ. Mìnsk: Navuka ì tèhnìka [Лексікалогія сучаснай беларускай літаратурнай мовы. 1994. Рэд. А. Баханькоў. Мінск: Навука і тэхніка]. 
Lûbeckaâ Kacâryna. 2002. Z gìstoryì nâmecka-belaruskaj, belaruska-nâmeckaj leksìkagrafì̀ ì tèrmìnagrafiì. Rèd. G. Cyhun. Mìnsk: Belaruskì knìgazbor [Любецкая Кацярына. 2002. 3 гісторыі нямецка-беларускай, беларуска-нямецкай лексікаграфіi і тэрмінаграфіi. Рэд. Г. Цыхун. Мінск: Беларускі кнігазбор].

Lûbeckaâ Kacâryna. 2017. Osobennosti formirovaniâ belorusskogo naučnogo âzyka v načale XX v. "Zapiski z ukraïns'kogo movoznavstva”. Vip. 24. U 2-h tomah. T. 1. Odessa: Poliprint: 299-306 [Любецкая Екатерина. 2017. Особенности формирования белорусского научного языка в начале ХХ в. "Записки з українського мовознавства". Вип. 24. У 2-х томах. Том 1. Одесса: ПолиПринт: 299-306].

Mova "Našaj nivy". Semantyka. Stylistyka. 2014. Rèd. V. Lemcûgova. Mìnsk: Belaruskaâ navuka [Мова "Нашай нівы”. Семантыка. Стылістыка. 2014. Рэд. В. Лемцюгова. Мінск: Беларуская навука].

"Naša nìva”. 1911; 1912 ["Наша ніва". 1911; 1912].

Šakun Leǔ. 1995. Gìstoryâ belaruskaga movaznaǔstva. Mìnsk: Unìversìtèckae [Шакун Леў. 1995. Гісторыя беларускага мовазнаўства. Мінск: Універсітэцкае].

Turonak Ûry. 1993. Belarus' pad nâmeckaj akupacyâj. 1993. Mìnsk: Belarus' [Туронак Юры. 1993. Беларусь пад нямецкай акупацыяй. Мінск: Беларусь].

Vysockaâ Zorâna. 2013. Razvitie naučnogo stilâ ukrainskogo literaturnogo âzyka konca $X I X$ - načala XX vv. "Vestnik Tomskogo gosudarstvennogo universiteta". № 375, 21-25 [Высоцкая Зоряна. 2013. Развитие научного стиля украинского литературного языка конца XIX - начала XX в. "Вестник Томского государственного университета". № 375, 21-25].

Zaprudskì Sârgej. 2013. Belaruskae movaznaǔstva ì razvìccë belaruskaj litaraturnaj movy: 1920-1930-â gady. Mìnsk: BDU [Запрудскі Сяргей. 2013. Беларускае мовазнаўства і развіццё беларускай мовы: 1920-1930-я гады. Мінск: БДУ].

ABSTRACT: The article analyzes the conditions and formation features of the scientific style of the Belarusian literary language of the early XX century (1900-1920), which came to be the basis for the formation of the scientific style in its further development in modern language. Emphasis is placed on the socio-historical and cultural-political context of the formation of the Belarusian scientific language in the early XX century, the role of scientific institutions of that time, popular science and scientific-educational works presented incertain fields under relevant names in the development of the scientific style of the Belarusian language in that period. The issues of Belarusian terminology formation are actualized, lexical, morphological and syntactic features of the language of science are outlined. The characteristic linguistic and stylistic features of scientific works, as well as their genre affiliation and structure are identified.

KEYWORDS: Belarusian language, literary language, scientific language, scientific style, terminology, linguistic and stylistic features.

STRESZCZENIE: W artykule przeanalizowano warunki i zbadano cechy kształtowania się stylu naukowego białoruskiego języka literackiego na początku XX wieku (19001920), który stał się podstawą kształtowania stylu naukowego w dalszym jego rozwoju we współczesnym języku białoruskim. Nacisk kładziony jest na społeczno-historyczny i kulturowo-polityczny kontekst kształtowania się białoruskiego języka naukowego na początku XX w., rolę instytucji naukowych tamtych czasów, prac popularnonaukowych i naukowo-dydaktycznych prezentowanych w poszczególnych gałęziach przemysłu, w rozwoju stylu naukowego języka białoruskiego omawianego okresu. Zaktualizowano zagadnienia dotyczące powstawania białoruskiej terminologii, zarysowano leksykalne, morfologiczne 
i składniowe cechy języka nauki. Wyróżniono charakterystyczne cechy językowe prac naukowych, a także ich przynależność gatunkową i strukturę.

SŁOWA KLUCZOWE: język białoruski, język literacki, język naukowy, styl naukowy, terminologia, cechy językowo-stylistyczne

РЭЗЮмЭ: У артыкуле прааналізаваны ўмовы і разгледжаны асаблівасці фармавання навуковага стылю беларускай літаратурнай мовы пачатку XX ст. (19001920 гг.), якія сталі асновай для станаўлення навуковага стылю ў сучаснай мове. Акцэнтавана ўвага на сацыяльна-гістарычным і культурна-палітычным кантэксце фармавання беларускай навуковай мовы ў пачатку XX ст., ролі навуковых устаноў таго часу, навукова-папулярных і навукова-вучэбных прац, прадстаўленых па асобных галінах назвамі, у развіцці навуковага стылю беларускай мовы адзначанага перыяду. Актуалізаваны пытанні станаўлення беларускай тэрміналогіі, акрэслены лексічныя, марфалагічныя і сінтаксічныя адметнасці мовы навукі. Адзначаны характэрныя лінгвістылістычныя асаблівасці навуковых прац, а таксама іх жанравая прыналежнасць і структура.

КЛЮЧАВЫЯ СЛОВЫ: беларуская мова, літаратурная мова, навуковая мова, навуковы стыль, тэрміналогія, моўна-стылістычныя асаблівасці. 